\title{
Review \\ Inflammatory Bowel Disease: New Insights into the Interplay between Environmental Factors and PPAR $\gamma$
}

\author{
Giulia Caioni ${ }^{1}$, Angelo Viscido ${ }^{1}{ }^{(0}$, Michele d'Angelo ${ }^{1} \mathbb{C}$, Gloria Panella ${ }^{1,2} \mathbb{D}^{\mathbb{D}}$, Vanessa Castelli ${ }^{1}{ }^{1}$, \\ Carmine Merola ${ }^{2}$, Giuseppe Frieri ${ }^{1}$, Giovanni Latella ${ }^{1}\left(\mathbb{D}\right.$, Annamaria Cimini ${ }^{1,3}$ and Elisabetta Benedetti ${ }^{1, *}$ (i) \\ 1 Department of Life, Health and Environmental Sciences, University of L'Aquila, 67100 L'Aquila, Italy; \\ giulia.caioni@guest.univaq.it (G.C.); angelo.viscido@univaq.it (A.V.); michele.dangelo@univaq.it (M.d.); \\ gloria.panella86@gmail.com (G.P.); vanessa.castelli@univaq.it (V.C.); giuseppe.frieri@univaq.it (G.F.); \\ giovanni.latella@univaq.it (G.L.); annamaria.cimini@univaq.it (A.C.) \\ 2 Faculty of Bioscience and Technology for Food, Agriculture and Environment, University of Teramo, \\ Via Balzarini 1, 64100 Teramo, Italy; cmerola@unite.it \\ 3 Sbarro Institute for Cancer Research and Molecular Medicine and Center for Biotechnology, \\ Temple University, Philadelphia, PA 19122, USA \\ * Correspondence: elisabetta.benedetti@univaq.it; Tel.: +39-0862-433267
}

Citation: Caioni, G.; Viscido, A.; d'Angelo, M.; Panella, G.; Castelli, V.; Merola, C.; Frieri, G.; Latella, G.; Cimini, A.; Benedetti, E. Inflammatory Bowel Disease: New Insights into the Interplay between Environmental Factors and PPAR $\gamma$. Int. J. Mol. Sci. 2021, 22, 985. https://doi.org/10.3390/ijms22030985

Academic Editor: Iwona Bogacka Received: 23 December 2020

Accepted: 18 January 2021

Published: 20 January 2021

Publisher's Note: MDPI stays neutral with regard to jurisdictional claims in published maps and institutional affiliations.

Copyright: (c) 2021 by the authors. Licensee MDPI, Basel, Switzerland. This article is an open access article distributed under the terms and conditions of the Creative Commons Attribution (CC BY) license (https:// creativecommons.org/licenses/by/ $4.0 /)$.

\begin{abstract}
The pathophysiological processes of inflammatory bowel diseases (IBDs), i.e., Crohn's disease (CD) and ulcerative colitis (UC), are still not completely understood. The exact etiology remains unknown, but it is well established that the pathogenesis of the inflammatory lesions is due to a dysregulation of the gut immune system resulting in over-production of pro-inflammatory cytokines. Increasing evidence underlines the involvement of both environmental and genetic factors. Regarding the environment, the microbiota seems to play a crucial role. Peroxisome proliferator-activated receptors (PPARs) are nuclear receptors that exert pleiotropic effects on glucose homeostasis, lipid metabolism, inflammatory/immune processes, cell proliferation, and fibrosis. Furthermore, PPARs modulate interactions with several environmental factors, including microbiota. A significantly impaired PPAR $\gamma$ expression was observed in UC patients' colonic epithelial cells, suggesting that the disruption of PPAR $\gamma$ signaling may represent a critical step of the IBD pathogenesis. This paper will focus on the role of PPAR $\gamma$ in the interaction between environmental factors and IBD, and it will analyze the most suitable in vitro and in vivo models available to better study these relationships.
\end{abstract}

Keywords: PPAR $\gamma$; pathophysiological processes of IBD; environmental factors; IBD models

\section{Introduction}

The worldwide epidemiology of inflammatory bowel diseases (IBDs), such as Crohn's disease (CD) and ulcerative colitis (UC), has been influenced mainly by industrial progress and the improvement of human living conditions [1]. The increasing incidence and prevalence of IBD in developing countries suggest a connection with a westernized lifestyle and changed habits. The etiopathogenesis of IBD is not entirely understood. However, it is hypothesized to be related to a mixture of factors, including genetic susceptibility, dysregulation of the gut immune system, and environmental elements in conjunction with the microbiota. There is a need for complete information about these diseases since they represent an expanding global health problem, the costs of which are challenging to manage.

$\mathrm{CD}$ and UC are chronic inflammatory disorders with distinct clinical characteristics. $\mathrm{CD}$ can affect all gastrointestinal tract segments (most commonly the terminal ileum and colon) in a non-continuous manner, causing a typically asymmetrical, segmental, and transmural inflammation. CD complications include abscesses, fistulas, and strictures, and many patients need surgical procedures. UC involves the colonic mucosal surface, primarily affecting the rectum and, in some cases, the entire colon in a continuous manner. Depending on the extent of inflammation, UC can evolve into several forms, from proctitis 
to left-sides colitis or pancolitis [2]. Behind the different characteristics, CD and UC share almost common features regarding risk factors, symptoms, clinical course, complications, and the absence of a definitive cure. The current therapeutic approaches aim to reduce intestinal inflammation and, more specifically, block pro-inflammatory cytokines. However, the conventional therapy of IBD, i.e., salicylates, steroids, and immunosuppressants reduce the mortality, but not the rate of complications and surgery; the latter is required in up to $70 \%$ of CD and $20 \%$ of UC patients during their lifetime. The introduction of biological therapies, i.e., anti-tumor necrosis factor-alpha (TNF- $\alpha$ ), anti- $\alpha 4 \beta 7$ integrin, and antiinterleukins 12/23 antibodies, caused a revolution in the treatment of IBD; however, they reduced hospitalization, complications, and surgery only in the short- and medium-term. For these reasons, it is necessary to find personalized treatments employing new strategies for drug monitoring and, above all, identifying useful targets.

Concerning the underlying mechanism, IBD's pathogenesis seems to be related to an alteration in the innate immune system, including epithelial barrier defects with changes in E-cadherin, $\beta$-catenin, and claudins expression [3] and an inadequate expression of antimicrobial peptides. The gut immune homeostasis can be disrupted by innate immune cells contribution (neutrophils, dendritic cells, and macrophages) and the release of inflammatory mediators [4]. IBDs are typically characterized by high levels of cytokines, such as TNF- $\alpha$, IL-6, IL- 8 (one of the first chemokines described), IL-12, and chemokines such as chemokine ligand 2 , chemokine ligand 3 , and chemokine ligand 1 in colon tissues [5]. However, the role of adaptive immunity cannot be omitted since, in CD and UC patients, an alteration in immunoglobulin subclass production has been found [6]. Among other pathogenic components, there is an impairment in Peroxisome proliferator-activated receptors- $\gamma(\operatorname{PPAR} \gamma)$ activity, abnormalities of the enteric nervous system, genetic variants, and the presence of regulatory RNAs [4]. The high expression of PPAR $\gamma$ in the bowel has already been demonstrated [7], and several studies have shown its role in human colonic inflammation [8] along with the involvement of immune system response [9]. Notably, mesalazine, the most used drug in UC, binds and activates PPAR $\gamma$ [10]. Specifically, mesalazine enhances PPAR $\gamma$ expression and promotes its translocation from the cytoplasm to the nucleus [10]. Different xenobiotics and environmental pollutants can influence and alter the Peroxisome proliferator-activated receptors (PPAR) signaling pathway [11]. This evidence suggests a relationship between external factors and the onset of gut inflammation diseases.

This review analyzes and discusses the complex interaction of environment and PPAR $\gamma$ mediated-pathways as part of IBDs' pathogenesis. It will describe the current suitable in vitro and in vivo models with particular attention to each one's advantages and disadvantages. It will contribute towards a better understanding of PPAR $\gamma$ biology to expand the effective treatment strategies and improve patients' conditions.

\section{PPARs: Crosstalk between Metabolism and Inflammation}

PPARs are ligand-dependent transcription factors and belong to nuclear hormone receptors' superfamily, playing an important role in lipid and glucose metabolism [12]. In mammals, three isoforms of PPARs have been identified: PPAR $\alpha$ or NR1C1, PPAR $\beta / \delta$ or NR1C2, and PPAR $\gamma$ or NR1C, each of them encoded by a different gene. They share a similar structure. The ability to bind agonists is mediated by a ligand-binding domain (LBD) in the C-terminus, while the DNA binding domain is in the $\mathrm{N}$-terminus. These receptors can be activated by natural fatty acids and eicosanoids or synthetic ligands, which are used in the clinical management of metabolic diseases, such as fibrates, with cardioprotective properties [13], and thiazolidinediones, used in the treatment of diabetes mellitus type 2 [14]. After interaction with agonists, they are translocated in the nucleus, and their function depends on the heterodimerization with retinoid $X$ receptor (RXR). The heterodimers bind to sequence-specific PPAR response elements (PPREs), stimulating the target genes' transcription [15]. 
The members of the PPARs family show a wide range of actions on glucose and lipidic homeostasis, and they share many similarities in terms of structure and function; however, each isoform has a specific physiological activity, influenced by their tissue distribution.

PPAR $\alpha$ is expressed in tissues that require a large amount of energy, principally the liver, kidney, and skeletal muscle; its localization has also been demonstrated in cardiomyocytes, intestinal mucosa, adrenal gland, brown adipose tissue, and brain $[16,17]$. It is involved in the catabolism of fatty acids and their oxidation [18]. Regarding PPAR $\beta / \delta$, this isoform is involved in several processes, including cell proliferation, differentiation, migration, and apoptosis. Its activity is also related to glucose and cholesterol homeostasis, insulin sensitivity, and angiogenesis $[17,19]$. It is ubiquitously expressed but particularly abundant in the gastrointestinal tract, kidneys, skeletal muscle, and brain [20]. PPAR $\gamma$ is abundantly expressed in white and brown adipose tissue, where it plays a crucial role in regulating adipogenesis, energy balance, and lipid biosynthesis. It is also expressed in the intestines, liver, kidneys, brain, immunological system, and muscles [17,21].

PPARs are usually described as the main actors in lipid and glucose metabolism, but much evidence indicates their involvement in controlling inflammatory responses and inflammation-related disorders such as fibrosis and cancer. In addition to their known anti-inflammatory action, PPARs also modulate fibrogenesis and carcinogenesis.

It has been reported that PPARs have anti-inflammatory potential, modulating several points of inflammatory pathways. Inflammation consists of a dynamic sequence of phenomena, including the release of mediators that leads to vasodilatation, increased blood flow, vascular permeability, and recruitment of polymorphonuclear cells, particularly neutrophils in acute phase of inflammatory process, whereas mononuclear cells, macrophages, T- and B-lymphocytes are in chronic immunomediated inflammation. PPARs could intervene at each level of these processes. For example, PPAR $\alpha$ can negatively interfere with the NF- $\mathrm{kB}$ signaling pathway, repressing several inflammatory genes such as VCAM-1, COX-2, and IL-6 [22]. PPAR $\alpha$ is also involved in inhibiting the expression of inducible nitric oxide synthase [23] and TNF- $\alpha$ in macrophages [24]. PPAR $\beta / \delta$ activity is induced in the host inflammatory response in the skin, and it results in being up-regulated in keratinocytes as a consequence of external triggers. The activation of PPAR- $\beta / \delta$-pathway determines the expression of genes related to keratinocyte differentiation, survival, and repair [25]. Other studies focused on the role of PPAR $\beta$ / $\delta$ in attenuating atherosclerosis progression, revealing that this isoform has an HDL-raising effect and anti-inflammatory activity within the vessel wall, where it participates in the down-regulation of chemokines production [26].

Mechanisms of the anti-inflammatory effects of PPAR $\gamma$ include the inhibition of the transcriptional activity of NF- $\mathrm{KB}, \mathrm{STAT}-1$, and AP-1 [27]. A direct relationship between TNF- $\alpha$ adipocyte secretion and a decrease in expression of PPAR $\gamma$ has been reported [28]. Moreover, negative regulation of PPAR $\gamma$ contributes to the antiadipogenic effects of TNF- $\alpha$, whose increased production is relevant in obesity states [29]. In fact, several studies have also demonstrated a metabolic benefit related to the anti-inflammatory effects of targeting $\operatorname{PPAR} \gamma[30]$.

All PPARs isoforms can have a role in regulating inflammatory responses, employing their interaction with various transcription factors stimulating inflammation, signal transducer, the formation of complexes between co-activators and co-repressors, and the modulation of different kinases [31].

Thus, the need for more in-depth knowledge of PPARs activity derives from their key role in various metabolic processes, including lipid and glucose homeostasis and inflammatory disease, which makes them the ideal target for developing new pharmacological strategies.

PPAR agonists are currently used to treat many diseases, such as hyperlipidemia, insulin resistance, type 2 diabetes, cardiometabolic syndrome, and atherosclerosis. The latest generation of agonists is represented by the selective peroxisome proliferator-activated receptor modulators, indicated as SPPARMs. With respect to traditional ligands, they can act as dual partial agonists, binding to two isoforms of receptors. Moreover, they have 
the ability to produce particular conformational changes, which leads to the preferential activation of transcriptional factors [32]. Further progress is represented by pan agonists, whose beneficial effects result from the ability to bind and activate the diverse isoforms of PPARs, reinforcing the single activation mediated by selective agonists [33].

\section{The Importance of PPAR $\gamma$ in IBDs}

Maintaining a healthy gastrointestinal tract depends on external factors (diet, chemicals, drugs, stress) or endogenous factors (genetics, microbiota, efficient immune responses). The loss of equilibrium between these factors may determine the onset of diseases. However, the elements contributing to inflammation and bowel disease are not clear. It is not possible to define a single factor or gene responsible for these modifications. Considering the critical role of PPARs in inflammation, many studies have focused on the possible correlation between these receptors, IBD, and cancer. In particular, chronic intestinal inflammation represents the leading risk factor for the development of gastrointestinal malignancy. Patients with UC and CD have a significantly higher cancer susceptibility [34].

The role of PPARs in inflammatory responses, which has already been described above, makes them possible actors in the pathogenesis of intestinal disorders and cancer. Particular attention has been given to PPAR $\gamma$ since it is abundantly expressed in epithelial cells in the large and small intestines [7]. Although the first evidence on the potential link between PPAR $\gamma$ and intestinal disease established a correlation between this receptor expression and an increase in colon tumorigenesis, recently, many researchers have re-examined the association between PPAR $\gamma$ and the risk of colorectal cancer (CRC) [35-38].

Genetic studies have demonstrated that heterozygous intestinal-specific PPAR $\gamma$ knockout enhanced tumor growth, evidencing PPAR $\gamma$ as a tumor resistance factor [39]

Interestingly, the activation of PPAR $\gamma$ by mesalazine could be responsible for CRC prevention observed with this drug in IBDs [40]. In immune-deficient mice engrafted with human CRC cells, mesalazine administration reduces xenografts' growth via a PPAR$\gamma$-dependent mechanism [41]. Activation of PPAR $\gamma$ by mesalazine is accompanied by induction of the tumor suppressor gene PTEN, activation of caspase- 8 and caspase-3, and diminished expression of surviving and X-linked inhibitor apoptosis protein [42].

However, the role of PPAR $\gamma$ is not only related to tumorigenesis, because a lot of evidence suggests its involvement in inflammation diseases. For example, a down-regulation has been reported in PPAR $\gamma$ expression in UC [37], and a negative correlation has also been hypothesized with UC progression, because of the low level of PPAR $\gamma$ mRNA in the mucosa of active UC patients compared with UC patients in remission [8]. Sugawara et al. demonstrated positive evidence for the association of allelic variation of the PPAR $\gamma$ gene and $C D$ [43]. These findings suggest that chronic inflammation could be caused by decreased levels in PPAR $\gamma$ expression in the colon.

Among the distinctive features of IBDs' pathogenesis, there is real deregulation in cytokine production in inflamed colon areas. Studies on human biopsies and in vitro models have demonstrated that a broad set of molecules dominates the mucosal response, where the contribution of epithelial cells is predominant [44]. These soluble mediators include pro-inflammatory cytokines, such as TNF- $\alpha$, IFN- $\gamma$, IL-6, IL-12, IL-21, IL-23, IL-17, and anti-inflammatory cytokines, such as IL-10, TGF $\beta$, IL-35 [4] and chemokines CXCL1, CXCL2, CXCL3, CCL20 [44]. In particular, the elevated production of IL-12, IL-23, IFN- $\gamma$, and IL-17 seems to be characteristic of CD, while UC is usually associated with increased production of IL-3, IL-5, and IL-9 [5].

PPAR $\gamma$ distinguishes itself for the protective effects, including the modulation of cytokine/chemokine production and the negative regulation of macrophage activation [45]. In this scenario, it is not difficult to understand why studies have abundantly focused on the $\gamma$-isoform of PPARs and the possible mechanism through which this receptor could be involved in bowel inflammation (Figure 1). 


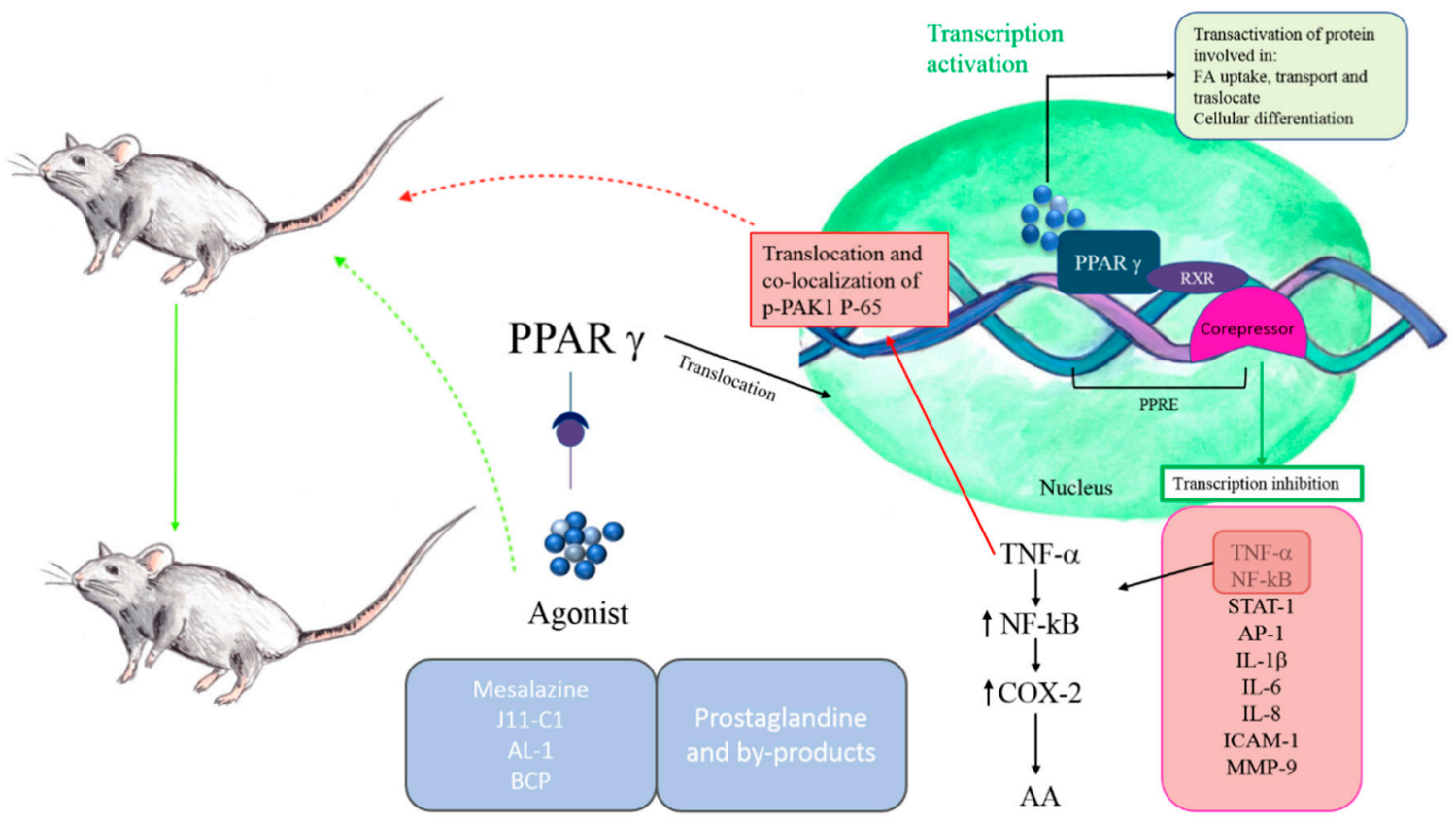

Figure 1. Peroxisome proliferator-activated receptors- $\gamma(\operatorname{PPAR} \gamma)$ in IBDs. PPAR $\gamma$ belongs to the family of nuclear receptors. Its activation involves the translocation in nucleus and the heterodimerization with retinoid X receptor (RXR). The heterodimers bind to sequence-specific PPAR response elements (PPREs), stimulating the transcription of target genes. Corepressors maintain the target genes inactivated in absence of PPAR $\gamma$ ligands. The protective effects of PPAR $\gamma$ include the modulation of pro-inflammatory cytokines production, such as TNF $\gamma$, IL-6, the inhibition of transcription factors, including NF-kB, STAT-1, AP-1, and intercellular adhesion molecule and MMP-9. PPAR $\gamma$ also determines the downregulation of p65 expression and IkappaB kinase. In contrast, TNF- $\alpha$ activates NF-kB, which stimulates COX-2 to convert arachidonic acid in prostaglandins. The anti-inflammatory properties of prostaglandins are related to their ability to bind PPAR $\gamma$, blocking NF-kB downstream events. PPAR $\gamma$ synthetic agonists can ameliorate IBD inflammation.

The activation of PPAR $\gamma$ determines a decrease in the production of pro-inflammatory cytokines, such as TNF- $\alpha$ and IL- 6 , and the inhibition of transcription factors, including NF- $\mathrm{BB}, \mathrm{AP}-1$, STAT-1, and Intercellular Adhesion Molecule (ICAM-1), and matrix metallopeptidase 9 (MMP-9) [46].

Several studies have shown that PPAR $\gamma$ synthetic agonists can ameliorate gut inflammatory phenomena. Bassaganya-Riera et al. [47], using in vivo models of IBD, provided molecular evidence that conjugated linoleic acid reduces colitis inflammation employing a $\operatorname{PPAR} \gamma$-dependent mechanism.

More recently, it was shown that the synthesized jasmonate analog $\mathrm{J} 11-\mathrm{Cl}$ (2hydroxyethyl 5-chloro-4,5-didehydrojasmonate), structurally similar to cyclopentenone prostaglandin $15 \mathrm{~d}-\mathrm{PGJ}_{2}$, increases PPAR $\gamma$ activity and exerts anti-inflammatory effects, determining a less severe form of intestinal inflammation in dextran sodium sulfate (DSS)induced colitis in mice. The treatment reduced pro-inflammatory cytokines and chemokines and increased anti-inflammatory cytokines and growth factors [48]. Another research study also supports the role of PPAR $\gamma$ in the amelioration of inflammatory bowel disease. In trinitrobenzene sulfonic acid (TNBS)-induced colitis mice, the andrographolide-lipoic acid conjugate (AL-1) administration alleviates inflammation through inhibiting the expression of TNF- $\alpha$, IL- $1 \beta$, and IL- 6 and down-regulating the expression of p65 and p-IкB, key regulators of NF- $\mathrm{kB}$ pathway. Moreover, COX-2 levels, which are regulated by NF- $\mathrm{kB}$, were reported to control levels, and the expression of PPAR $\gamma$ was increased in AL- 1 treated groups [49]. The modulation of PPAR $\gamma / \mathrm{NF}-\mathrm{KB}$ cascade in intestinal inflammation is related to p21-activated kinase 1 (PAK1), the results of which overexpressed and activated in IBDs [50]. In particular, TNF- $\alpha$ is responsible for the translocation and co-localization of 
p-PAK1 and p-65 in the nucleus. These events determine the transcriptional activation of NF-kB. Activated PAK1 blocks PPAR $\gamma$, increasing accumulation of p-65.

TNF- $\alpha$ stimulation can also induce the expression of COX-2, whose transcription can be regulated by several factors such as NF- $\mathrm{kB}$ and PPARs [51]. It has been demonstrated that this pro-inflammatory enzyme is induced in the human inflamed large intestine and IL-10 deficient mouse model of IBD [52,53]. COX-2 metabolizes free arachidonic acid (AA) into prostanoids, such as prostaglandins (PGs) and thromboxanes (TXs). The by-products cyclopentenone prostanoids, including 15-deoxy-12,13-didehydro-14,15-didehydro-PGJ 2 $\left(15 \mathrm{~d}-\Delta^{12,14}-\mathrm{PGJ}_{2}\right), 12,13$-didehydro-PGJ $2\left(\Delta^{12}-\mathrm{PGJ}_{2}\right)$, and PGA ${ }_{2}$, are ligands of PPAR $\gamma$, suggesting an interaction between this receptor and COX-2 during inflammation [54,55]. Prostaglandins exert anti-inflammatory effects by inhibiting NF- $\mathrm{kB}$ mediated by the blockage of IkappaB kinase and activation of PPAR $\gamma$ [56].

Other evidence suggested the role of the cannabinoid system in IBD, since cannabinoid receptors 1 and 2 (CB1 and CB2) are increased in IBD colonic tissue [57]. Moreover, a strong increase of endocannabinoids (especially anandamide) was found in biopsies from patients with untreated UC [58]. The results of several studies support the hypothesis of a cross-talk between PPAR $\gamma$ and the cannabinoid system in reducing inflammation. Liu et al. indicated PPAR $\gamma$ as a molecular target for synthetic cannabinoids, demonstrating its possible use in various treatments [59]. Furthermore, the sesquiterpene $\beta$-caryophyllene (BCP) can reduce DSS-induced colitis in mice with a mechanism associated with CB2 and PPAR $\gamma$, which leads to the inhibition of pro-inflammatory cytokines and NF- $\mathrm{BB}$ [57].

\section{Perturbation of Gut Microbiota Homeostasis: From Environmental Risk Factors to PPAR $\gamma$ Activation}

The gut microbiota has an essential role in preserving intestinal homeostasis, but it is sensible to environmental pollutants and external factors. The microbial community consists of at least $10^{11}-10^{12}$ bacterial cells per millimeter, and the principal phyla include Firmicutes, Bacteroidetes, Actinobacteria, Proteobacteria, Fusobacteria, and Verrucomicrobia [60].

$\operatorname{PPAR} \gamma$ participates in the maintenance of innate antimicrobial immunity, regulating the expression of a subset of $\beta$-defensins in the colon, such as mDefB10 (mice) and DEFB1 (humans) [61]. In particular, a defective killing of Bacteroides fragilis, Enterococcus faecalis, and Candida albicans was observed in Ppar $\gamma+/-$ mice, supporting a PPAR $\gamma$ antimicrobial activity. Regarding the microbiota, alterations in gut-associated microbial community could determine dysbiosis and the onset of inflammatory diseases. It was found that the PPAR $\gamma$ signaling influences the luminal bioavailability of oxygen via $\beta$-oxidation, preventing the expansion of pathogenic Escherichia and Salmonella [62]. This observation also suggests the implication of PPAR $\gamma$ in the maintenance of gut microbial health (Figure 2).

Moreover, bacteria can generate metabolites that could interfere with PPAR dependent pathways. In support of this evidence, some studies showed that microbiota metabolites butyrate and propionate increase PPAR $\gamma$ transcriptional activity in HT-29 cells [63]. In IBD patients, the altered microbiota determines dysbiosis with a decrease in butyrate bacteria. The absence of butyrate is critical because it has the anti-inflammatory ability by promoting IL-10 secretion and inhibiting HDACs/NF-KB pathway and increasing PPAR $\gamma$ activity [63].

The treatment of Caco-2 cells with prebiotic oligosaccharides has been shown to induce PPAR $\gamma$, leading to an anti-inflammatory activity [64]. The beneficial role of prebiotics can be justified by considering that only a healthy gut microbiota is useful in protecting against intestinal inflammation. In light of this, many therapeutic strategies are aimed at restoring the bacterial community. Probiotics and prebiotics like Lactobacillus, Bifidobacterium, Lactulose, Lactosucrose, inulin, oligofructose are just some of these "pharmabiotics" [65].

It has been demonstrated that the proportions of microorganisms may vary according to body fat in humans so that weight loss and weight gain influence the composition of intestinal biota [66]. Other factors contribute to these modifications: diet, metabolic disorders, stress, and chemical compounds. In particular, gut bacteria may interact with chemicals in several ways. First of all, microbes may directly metabolize synthetic molecules ingested 
with food, or metabolites released by the liver into the bile which then pass into the intestinal lumen. However, these substances can induce dysbiosis interfering with bacterial enzymatic activity [67].

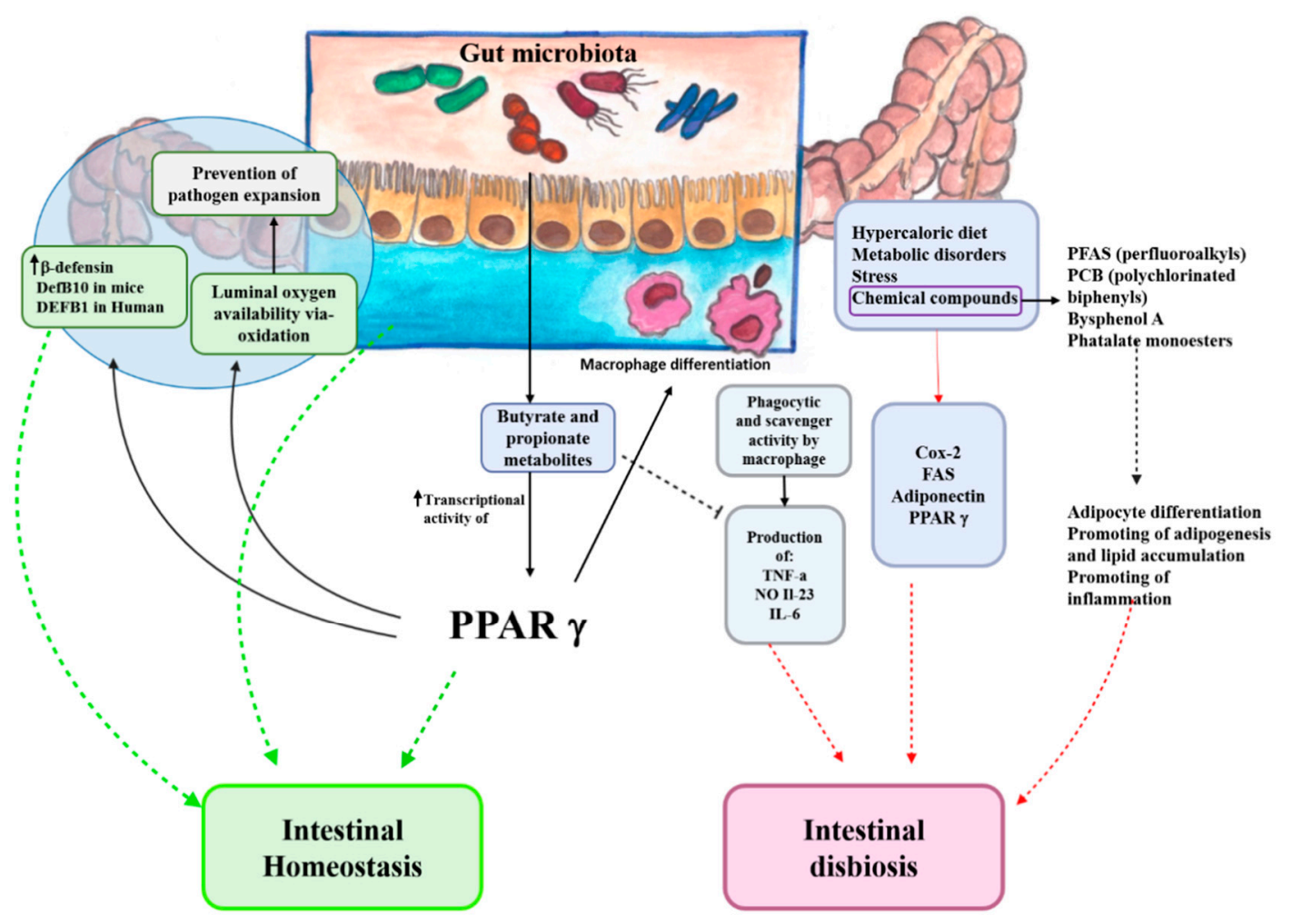

Figure 2. Synergistic action supported by the gut microbiota and PPAR $\gamma$ in the maintenance of intestinal homeostasis. The microbial community produces short-chain fatty acids (SCFAs), such as butyric and propionic acid, which increase the transcriptional activity of intestinal PPAR $\gamma$, leading to a higher expression of $\beta$-defensins (DEFB1 in human and DEFB10 in mice) in the colon. Moreover, PPAR $\gamma$ drives the energy metabolism to $\beta$-oxidation: the luminal oxygen availability decreases, preventing the expansion of facultative anaerobic pathogens. PPAR $\gamma$ is also involved in macrophage activation and function, influencing the phagocytic and scavenging activity. Intestinal dysbiosis is the result of endogen and exogen factors. Among the external factors, hypercaloric diet, stress, metabolic disorders, and exposure to chemical compounds permit a state of low-grade inflammation to be established. The reasons are to be found in the altered expression of PPAR $\gamma$ and other inflammation markers. Several chemical compounds may determine alteration in adipose tissue function. Since adipose tissue contributes to intestinal homeostasis, the impairment of PPAR $\gamma$ activity may indirectly promote the onset of intestinal disorders.

Additionally, in the obesity condition, the microbiota is compromised by the hypercaloric diet. This condition leads to an impairment of the epithelial barrier, which determines an increase in its permeability. Gut microbial lipopolysaccharide (LPS) is responsible for metabolic endotoxemia, to which macrophages respond, transforming to M1 phenotype [68]. Macrophages can be classified as inflammatory macrophages (M1), wound-healing (M2), and regulatory macrophages (Mreg) [69]. They differ from each other based on the conditions (cytokines) in which they are rising [70]. The cytokines are fundamental in macrophage polarization; for example, INF- $\gamma$ and TNF- $\alpha$ contribute to M1 polarization, while IL-4 polarizes M2, and the regulatory macrophage polarization is influenced by many signals, including IgG immune complexes, IL-10, prostaglandins, or apoptotic cells [70].

Interestingly, patients affected by inflammatory bowel diseases, even when they are in clinical and endoscopic remission maintain a "low-grade intestinal inflammation." The presence of a residual inflammation is familiar not only in IBDs, but also in type 2 diabetes, cardiovascular diseases, and obesity. The link between chronic or residual 
inflammation and diseases is modulated by macrophages, which are the primary producers of mediators such as IL-1, IL-6, TNF- $\alpha$, reactive oxygen intermediates [71]. In normal conditions, bone marrow-derived monocytes are recruited to the intestinal mucosa, where they exert pathogen scavenger activity through TLR4 receptor; they also produce antiinflammatory cytokines, such as IL-10. Macrophages participate in inflammatory response, secreting pro-inflammatory cytokines, including IL-23 and TNF- $\alpha$.

Macrophages are localized in the subepithelial lamina propria (LP), and they are identified by several markers, such as F4/80, CD64, and CD11b [72]. Moreover, the distinct properties of macrophages include: phagocytic and scavenger activity against bacteria and pathogens, maintenance of gut homeostasis through anti-inflammatory cytokines production, and eliminating commensals [73]. However, the failure in enteric bacterial tolerance may result in chronic inflammation. Pro-inflammatory macrophages produce large amounts of TNF- $\alpha$, nitric oxide (NO), IL-23, IL-1 $\beta$, and IL- 6 , which are part of anti-microbial activity even if they contribute to tissue damage [74].

The macrophage function is influenced by several factors, including dietary nutrients (fatty acids, vitamins, amino acids). In particular, it has been demonstrated that the treatment with n-butyrate causes a reduction of pro-inflammatory mediators (NO, IL-6, IL-12) produced by macrophages [75]. This evidence suggests an important link between gut microbiota and immune responses.

The precursors of intestinal macrophages are monocytes from bone marrow, and they migrate to the intestinal mucosa, recruited by IL- 8 and TGF- $\beta$ [76]. The subsequent polarization to anergic inflammation cells derives from signals, such as the inhibition of NF- $\mathrm{kB}$ by TGF- $\beta$ [77]. Cytokines and chemokines induce down-regulation of receptor TREM-1 (triggering receptor expressed on myeloid cells) on macrophages involved in potent inflammatory responses.

It has been demonstrated that TREM-1 is involved in IBDs. In particular, an increase in macrophages expressing TREM- 1 was observed in patients with inflamed mucosa. This condition leads to high levels of pro-inflammatory cytokines and chemokine (IL-6, IL-8, IL-1 $\beta$, TNF, etc.). The amplification of inflammatory response mediated by TREM- 1 exerts an essential role in exacerbating disease and damage in the mucosa layer [78]. Thus, IBDs and the persistence of signs and symptoms seem to be related to inappropriate macrophage responses, which determine the difficulty of eliminating bacteria. Macrophages also express $\operatorname{PPAR} \gamma$, and many studies are focused on the contribution to this receptor in macrophage differentiation [79], even if other groups define it as not being necessary in this process [80]. Heming et al. showed that the absence of PPAR $\gamma$ in macrophages determines alterations in differentiation pathways and influences the activity of phagocytosis and migration. Moreover, an increase in PPAR $\gamma$ expression can be observed after treatments with glucocorticoids (GC). They also demonstrated that macrophage migration is negatively controlled by $\operatorname{PPAR} \gamma$ [81]. These observations suggest that the differentiation and macrophages activity, which are implicated in chronic inflammation, can be modulated by ligands of PPAR $\gamma$.

\section{Chemical Compounds and PPAR $\gamma$ Activity}

Chronic inflammation is a key aspect not only in CD and UC but also in metabolic syndromes. The activation of inflammatory responses may be the result of the interaction between chemical compounds and PPAR $\gamma$. In particular, a class of substances named "obesogens" can influence PPAR $\gamma$ and indirectly the homeostasis of adipose tissue. These substances determine a greater susceptibility to the onset of bowel disease, promoting inflammation and dysregulation of metabolic processes. Thus, a correlation between environmental factors and IBDs can be supposed.

Adipose tissue is no longer considered mere storage of fat, but it has an active role in the synthesis and secretion of several hormones [82]. It also participates in bioactive peptide production, such as adipokines and several cytokines [83], produced by adipocytes and preadipocytes. 
The importance of adipose tissue's adequate functioning is reflected by the fact that every perturbation of tissue homeostasis has a systemic impact. Many genetic and environmental factors may determine the adipose tissue's remodeling, which is demonstrated to be highly dynamic. Two events may derive from these alterations: hyperplasia and hypertrophy of adipocytes [84].

In particular, adipocyte hypertrophy is typical in the obesity state, and it determines the increase in necrotic cell deaths, leading to activation in inflammatory responses and tissue dysfunction [85]. In fact, levels of pro-inflammatory cytokines, such as TNF- $\alpha$, IL-6, and IL- 8 become high, along with the presence of chemoattractant molecules, including MCP-1, which promotes the activity of macrophages and T-cells [86]. Thus, hypertrophic modifications are responsible for harmful consequences, which result in the dysfunction of adipose tissue. The hyperplastic expansion involves the differentiation of pre-adipocytes in adipocytes, where PPAR $\gamma$ and CCAAT / enhancer-binding protein families play a key role [87]. Hyperplasia leads to an increase in the number of adipocytes without influencing the number of inflammatory cytokines or immune cell recruitment. It represents a protective response against overnutrition [88] since it tries to counteract obesity-associated complications.

The adipose tissue also contributes to the maintenance of intestinal physiology, supporting the local host defenses and participating in immune system responses via adipokines secretion, which are hormone-like factors with auto- and paracrine effects. In particular, leptin and adiponectin were found to exert anti-inflammatory activity by enhancing IL-10 production by anti-CD3-stimulated lamina propria T-lymphocytes (LPL-T) in IBD patients [89]. Nishihara et al. [90] also demonstrated adiponectin's protective effect against DSS-induced colitis in adiponectin-knockout (APN-KO) mice.

Obesogens influence adipose tissue metabolism in terms of hyperplasia and hypertrophy of adipocytes. They can influence pre-adipocyte differentiation and alter energetic metabolism. Moreover, they can induce inflammation and oxidative stress. Regarding the effects on PPAR $\gamma$, these substances may increase its expression or bind it, leading to a series of events that culminate with the enhancement of adipogenesis [91].

Many groups of chemical compounds are shown to influence adipose tissue, such as pesticides, fungicides, byproducts of fuel burning such as polycyclic aromatic hydrocarbons (PAHs), components of plastics including bisphenol A (BPA) and its analogues, plasticizing agents used in cosmetics and medicines, or preservatives like parabens.

The anti-inflammatory properties of PPAR $\gamma$ can be modulated by the assumption of several dietary compounds, including glutamine, spicy food, flavonoids [92], or physical activity cardiorespiratory fitness [93]. However, the modulation of this receptor can be related to a large number of external factors. The necessity of deepening this relationship comes from identifying the environmental contribution to the onset of IBDs to implement prevention measures.

It is well-known that many chemicals and by-products of industrial activities can interfere with air, soil, and water quality, influencing the development of living creatures. The concern about these substances determines greater attention and awareness of a healthy lifestyle.

For example, people are exposed to endocrine-disrupting chemicals (EDCs), which are found in everyday products, such as plastic bottles, containers, food, cosmetics, pesticides, etc. EDCs include phthalates, phytoestrogens, triclosan dioxins, parabens, perand polyfluoroalkyl substances (PFAS), and polychlorinated biphenyls (PCBs). They influence hormonal homeostasis leading to a dysregulation of metabolic responses, including lipid metabolism and adipogenesis [94]. Several studies show a correlation between the activity of these substances and metabolic disruption [95]. Many studies confirmed the activation of PPAR $\gamma$ by chemical compounds. Hurst and Waxman [96] demonstrated the activation of human and mouse PPAR $\gamma$ by phthalate monoesters with an increase in adipocyte differentiation. 
Bisphenol A and its derivatives, used in plastic bottles, paper, and other daily products, showed an affinity to human PPAR $\gamma$ because of their structural similarity with $17 \beta$-estradiol [97].

The organotin compound tributyltin (TBT), used as biocide and fungicide, binds to PPAR $\gamma$, promoting adipogenesis and lipid accumulation [98].

PPAR $\gamma$ is a master regulator of lipid homeostasis and adipogenesis, and it also has an essential role in adipocyte differentiation. This concept suggests that any alterations or changes in PPAR- $\gamma$-mediated pathways could determine alterations in adipose tissue functions, promoting the onset of intestinal disease indirectly.

Limited experimental and epidemiological data suggest a direct relationship between environmental pollutants or contaminants and IBDs, and there is no clear evidence of the PPAR $\gamma$ involvement. However, this does not mean that external factors could not affect intestinal health. Only a few data are focused on the exposure to air pollution and the risk of IBDs [99] or the role of PFAS contained in drinking water and ulcerative colitis [100]. Still, there is no evidence of a direct connection between these (and other) chemicals and PPAR $\gamma$.

Probably and until proven otherwise, the environmental factors and pollutants are not directly correlated to IBDs, but they would contribute to enhancing the individual susceptibility to chronic disorders.

Environmental chemicals can also have a role in epigenetic modifications. Several studies were conducted to investigate the ability of air pollutants, endocrine-disrupting compounds, or metals to influence the genome in terms of methylation or histone modifications [101].

For example, maternal exposure to Bisphenol A in rat models results in DNA methylation of specific loci ( $A^{v y}$ and $\left.\mathrm{Capb}^{\mathrm{IAP}}\right)$ in fetal epigenome [102].

The strict relation between chemical compounds PPAR $\gamma$ and IBD is still unclear, but the possibility of a PPAR $\gamma$ epigenetic dysregulation is not remote. In fact, in colorectal tumorigenesis, the epigenetic mechanisms would imply changes in PPAR $\gamma$ promoter methylation [103].

Many compounds interfere with PPAR $\gamma$ signaling pathways at different levels. They can act as risk factors: hence the need to get new information by suitable experimental in vivo IBD models.

\section{Current Experimental Models of IBDs}

Tissue and cell culture methodologies significantly contributed to a better comprehension of the underlying mechanisms of IBDs (Figure 3). Among the human epithelial cell lines that have been used for years, there are T84, Caco-2, HT-29, HCA-7. Caco-2 and T84 are typically used as in vitro model systems of the epithelial barrier. In particular, Caco-2 cells allowed the study of the mechanism of transport and the absorption of chemical compounds through the epithelial barrier [104]. HT-29 cells are used to study the intestinal response to bacterial infection and the microbial interactions with the intestinal epithelium [105]. HCA-7 is useful for studying the role of COX-2 in cancer cells and the colorectal epithelial cell polarity [106].

It is well-known that the use of monolayer has some disadvantages related to the limits of bidimensional models. However, a major grade of complexity is reached by making use of co-cultures. Leonard et al. [107] designed a specific in vitro setup, consisting of Caco-2 cells, macrophages, and dendritic cells. This model determines the possibility of studying the mechanism of inflammation, typically present in IBDs. It overcomes the difficulties linked to the use of a monolayer, giving a whole point of view of inflammatory disorders.

Despite the disadvantages, the use of human cancer cell lines represents the starting point for the evaluation of several aspects in IBDs. First of all, the study of molecular processes requires a simple and standardized model. For example, the role of pro-inflammatory mediators on cells or main cellular modifications can be appreciated only by minimizing external fluctuations. Second, pharmacological studies and, in particular, the interaction of drugs with specific receptors cannot be understood in complex models, where many 
variables could influence the results. However, once these studies are completed, the research can focus on tridimensional models in order to expand knowledge and investigate other aspects.

Human epithelial cell lines used to study:
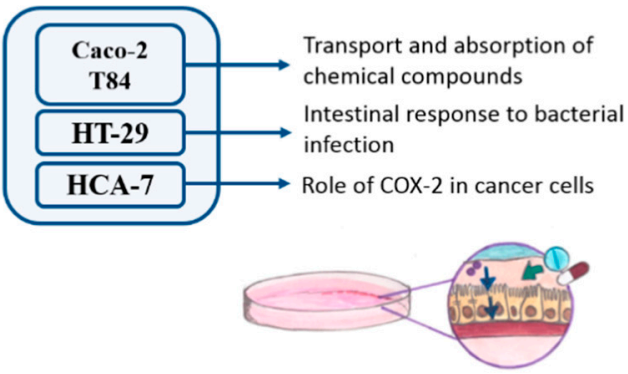

Organotypic culture (OTC) used to study:

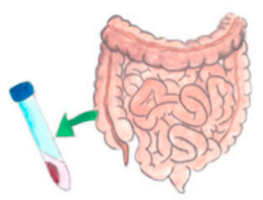

The beneficial effects of an anti-inflammatory drugs

\section{Organoids(enteroids or colonoids) used to :}

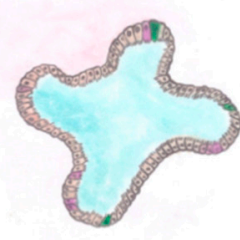

Improve the knowledge

of gastrointestinal disease

In vivo models used to:

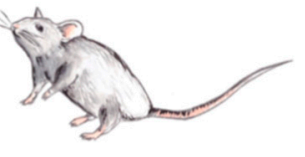

Murine models Es. SAMP1/YitFc (Samp)

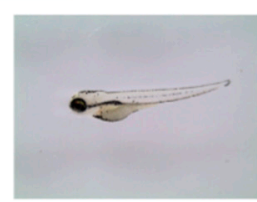

Larval and adults Zebrafish IBD models

Figure 3. Traditional and innovative in vitro and in vivo models of inflammatory bowel diseases (IBDs). The human epithelial cell lines principally used include: Caco-2, T-84, Ht-29, and HCA-7. They allow one to investigate the function of epithelial barrier in terms of transport and absorption of chemical compounds, and defense mechanisms against bacterial infections. Furthermore, the inflammatory responses in cancer cells may be evaluated. Organotypic culture gives some advantages in pharmacological studies, while organoids offer a more complete representation of intestinal structures with its three-dimensional characteristics. Among the in vivo models, mice are the most used and IBD-like inflammation can be easily induced by means of the exposition to chemical compounds, or using transgenic lines. Future directions may include the use of larval and adult zebrafish, which represent a useful alternative since the costs of management are lower and they allow an easier genetic manipulation and application of imaging techniques.

On the contrary, the organotypic cultures (OTC) allow filling the gap between the extreme simplicity of bidimensional cultures and the complexity of animal models. They are also used to model intestinal inflammation because it is possible to consider the role and the influence of the microenvironmental factors for a better in vitro simulation of physiological conditions. Specimens from patients are usually collected during colonoscopy, and the slices of tissue are transferred into appropriate culture conditions [108]. The applications of OTC are various and include the examination of the effects of therapeutic treatments. For example, biopsies from celiac disease patients have been used to investigate the beneficial effect of anti-inflammatory drugs used in IBD treatment. This study demonstrated that mesalazine induces PPAR $\gamma$ expression, inhibiting oxidative and nitrative species production on OTC [109].

However, new modelling strategies have been developed to improve the knowledge of gastrointestinal diseases. One experimental set-up consists of the embedding of human colonic crypts and intestinal stem cells in Matrigel; these cells form enterospheres; i.e., spherical structures with a lumen. After several days of isolation, the organization becomes more complex with the expansion in enteroids and colonoids, miming the structure of epithelium and crypts [110].

Regarding in vivo models, they can be classified based on how the intestinal inflammation is induced.

Dextran sulfate sodium (DSS) and trinitrobenzene sulfonic acid (TNBS) are used to induce colitis in animal (mouse) models. The advantages are mainly related to technical 
simplicity, and wild-type mice can be used. They allow studying innate immune mechanisms, epithelial injury, and the interaction with adaptative systems. However, neither can be considered a complete representation of colitis in humans [111]. Other models have been developed, such as the IL-10 knockout and the Mdr1a knockout models. They have particular translational relevance, especially in the study of IL-10 receptor polymorphisms involved in early childhood ulcerative colitis and MDR1 polymorphisms, which are associated with human ulcerative colitis [112]. T-cell transfer-induced is model of intestinal fibrosis, permitting the study of immune regulation, Treg, and integrins [113].

SAMP1/YitFc (Samp) mice represent a suitable model to study the underlined mechanisms of $C D$, since the onset of inflammation is spontaneous and localized in the ileum [111]. Moreover, these mice share features with human Crohn's diseases: in particular, PPAR $\gamma$ has been identified as a susceptible gene involved in the disease's onset both in SAMP/Yit mouse and human [43].

Although several models have been developed to gain insights into mechanisms of inflammation and lesions in IBDs, it is clear that the information is incomplete because of the impossibility of having all the same characteristics of the disease in one model. Therefore, the knowledge of inflammation disorders derives from the study of multiple different models. Moreover, the murine models' limitations are related to difficulties of genetic manipulation, use of imaging techniques, and high maintenance costs.

Given that several gut functions and immune genes are conserved between zebrafish and mammals, the zebrafish is an interesting model organism to investigate fundamental processes underlying intestinal inflammation and injury [114,115].

The advantages of using adult or larval zebrafish as a model for IBDs derive from their similarities with humans in terms of genes involved in intestinal disorders, immune system functions, and anatomical structure, even if Paneth cells and crypts were not detected along with the absence of stomach. Protrusions are called folds, resembling villi, whose size decreases from anterior to posterior part [116]. The intestinal epithelium consists of three types of differentiated cells: mucin-producing goblet cells, absorptive enterocytes, and endocrine cells in the anterior intestine. The submucosa seems not to be present in zebrafish. The smooth muscle layer is directly attached to the mucosa, even if it has a minor complexity. Lamina propria is similar to mammalian connective tissue, despite its simplicity [117]. Although this suggests that the zebrafish digestive system is less complex, the intestine maintains the same functions and organization as the mammal intestines. The rostral, the mid, and the caudal portions are analogs of mammalian small and large intestines [118]. During the developmental stages, the growth and the formation of a complete digestive tract can also be directly followed because of the optical transparency of embryos. Even the immune responses can be traced by means of live imaging techniques.

The zebrafish model allows the study of the innate and adaptative immunity based on the embryos' developmental stage. In fact, a functional adaptive response is absent during the first days of development, while the innate immunity plays the main role [119].

The larval gut uses antimicrobial peptides (AMPs) produced by epithelial cells as a defense tool against Gram-negative, Gram-positive, fungi, or bacteria [120]. Zebrafish has defensin-like genes, predominantly expressed in the mid intestine [121].

Chemical induced models are adapted from murine models, but they involve the immersion of zebrafish larvae in a specific chemical to permit intestinal exposure. For example, the exposure to TNBS determined a disruption of intestinal architecture and an imbalance of Protobacteria proportion and Firmicutes, which are correlated to enterocolitis severity [122]. It was demonstrated that the morphological and functional changes in zebrafish gut exposed to TNBS are not related to the chemical induction itself, but they are a consequence of the activation of inflammatory responses. Fleming et al. observed significant changes in goblet cell number and TNF- $\alpha$ levels. The model showed similarity with human Crohn's disease, especially for enlarged lysosomes toward the lumen of the gut's epithelial lining [123]. The composition of intestinal infiltrate was affected by 
the intestinal microbiota in adult zebrafish with oxalazone-induced colitis. In particular, variation in bacterial colonies could determine the severity of intestinal damage [124].

The assessment of these models can be done with the administration of anti-inflammatory drugs or antibiotics and the analysis of inflammation and intestinal function. The study of inflammation responses has also been performed by generating transgenic zebrafish with Green Fluorescent Protein expression in neutrophils. Renshaw et al. used this approach to overcome limitations related to histochemical technique so that a single larva could be analyzed using in vivo live imaging [125]. Interestingly, zebrafish, like mice, may be a more robust animal model to study host and microbe's interaction. Experiments in zebrafish demonstrated that the microbiota increased fat storage in adipose tissue [126] and stimulated fatty acid uptake in the intestinal epithelium and liver [127] suggesting that diet-induced alterations of microbiota could lead to IBD by disturbing the host energy balance. Moreover, studies in experimental animals have indicated that the intestinal microbiota plays a critical role in intestinal inflammation's pathogenesis [122,128,129].

The possibility of realizing chemical-induced models can be useful to determine the role of such environmental pollutants in the onset of inflammatory bowel disease. Moreover, the involvement of PPAR $\gamma$ during the inflammatory process can be investigated.

A single PPAR $\gamma$ ortholog has been identified in zebrafish, and it shows a high percentage of similarity with the human gene [130]. It has been demonstrated that PPAR $\gamma$ has an important role during early embryonic development; in particular, its early expression around the pancreas and swimming bladder area confirms that it is involved in lipid metabolism since these tissues are the first regions where adipocytes develop [130]. Alterations in zebrafish lipid metabolism showed common features with mammalians and even the presence of PPAR $\gamma$ [131].

This suggests that the interference on lipid homeostasis mediated by a chemical compound could affect PPAR $\gamma$ mediated pathways. Having examined the implications of this receptor in inflammation and the onset of IBDs, it can be postulated that every ligand could act as a risk factor.

For example, several studies showed that parabens, classified as endocrine disruptors, can interfere with adipocyte differentiation, promoting adipogenesis and modulating the expression of adipokines, adiponectin, and leptin [132]. The effects of these substances have been investigated in zebrafish, and the observations indicated that propylparaben interferes with lipid metabolism [133].

Other chemicals were the subject of studies, such as BPA [134], perfluorooctane sulfonate, and tributyltin [135]. Nevertheless, there is no clear evidence of the association between endocrine disruptors and the onset of IBDs in zebrafish. Furthermore, this lack of information determines the need for further investigations utilizing the design of a new kind of zebrafish IBD model.

\section{Conclusions}

The PPARs family is involved in inflammation responses associated with IBDs. Several studies have demonstrated the role of PPAR $\gamma$ in dysregulation of gut homeostasis and how it determines the characteristic features of the diseases. A better knowledge of the underlined mechanisms is essential for developing targeted therapeutic strategies, which represents the gold standard in personalized medicine. Until now, in vitro and in vivo models could not wholly satisfy this need since the onset of IBDs results from a mixture of risk factors, genetic susceptibility, food habits, dysregulation of immune responses, etc.

However, these hypotheses taken together could not totally explain the increase in terms of incidence and prevalence of IBDs worldwide.

Thus, there may be the contribution of external/environmental factors, which could increase individual susceptibility. Since the correlation between pollutants and IBDs has not been examined in-depth, it is necessary to define a new experimental setup.

Murine models are typically used to investigate etiopathogenesis of inflammation disorders, but they have limitations in terms of costs and techniques. 
In this scenario, zebrafish represent the possibility of filling the lack of knowledge representing a suitable model. It shares the main structural features of digestive systems or mechanism of inflammation and represents a simplified means of disserting the complex background of IBDs. PPAR $\gamma$ is well conserved in vertebrates and other isoforms, so the zebrafish model will be a useful tool to study the correlation between external factors and the activation of the $\gamma$-isoform dependent pathway.

Author Contributions: Conceptualization, A.V. and E.B.; writing-original draft preparation, G.C.; figure preparation, G.P. and G.C.; review and editing, A.C., G.L., G.F., M.d., V.C., and C.M. All authors have read and agreed to the published version of the manuscript.

Funding: This research was funded by the RIA funds E.B.

Conflicts of Interest: The authors declare no conflict of interest.

\section{References}

1. GBD 2017 Inflammatory Bowel Disease Collaborators The global, regional, and national burden of inflammatory bowel disease in 195 countries and territories, 1990-2017: A systematic analysis for the Global Burden of Disease Study 2017. Lancet Gastroenterol. Hepatol. 2020, 5, 17-30. [CrossRef]

2. Torres, J.; Mehandru, S.; Colombel, J.-F.; Peyrin-Biroulet, L. Crohn's disease. Lancet 2017, 389, 1741-1755. [CrossRef]

3. Gassler, N.; Rohr, C.; Schneider, A.; Kartenbeck, J.; Bach, A.; Obermüller, N.; Otto, H.F.; Autschbach, F. Inflammatory bowel disease is associated with changes of enterocytic junctions. Am. J. Physiol. Gastrointest. Liver Physiol. 2001, 281, G216-G228. [CrossRef]

4. De Souza, H.S.P.; Fiocchi, C. Immunopathogenesis of IBD: Current state of the art. Nat. Rev. Gastroenterol Hepatol 2016, 13, 13-27. [CrossRef]

5. Neurath, M.F. Cytokines in inflammatory bowel disease. Nat. Rev. Immunol. 2014, 14, 329-342. [CrossRef]

6. MacDermott, R.P.; Nash, G.S.; Bertovich, M.J.; Mohrman, R.F.; Kodner, I.J.; Delacroix, D.L.; Vaerman, J.-P. Altered patterns of secretion of monomeric IgA and IgA subclass 1 by intestinal mononuclear cells in inflammatory bowel disease. Gastroenterology 1986, 91, 379-385. [CrossRef]

7. Fajas, L.; Auboeuf, D.; Raspé, E.; Schoonjans, K.; Lefebvre, A.M.; Saladin, R.; Najib, J.; Laville, M.; Fruchart, J.C.; Deeb, S.; et al. The organization, promoter analysis, and expression of the human PPARgamma gene. J. Biol. Chem. 1997, 272, 18779-18789. [CrossRef]

8. Yamamoto-Furusho, J.K.; Peñaloza-Coronel, A.; Sánchez-Muñoz, F.; Barreto-Zuñiga, R.; Dominguez-Lopez, A. Peroxisome proliferator-activated receptor-gamma (PPAR- $\gamma$ ) expression is downregulated in patients with active ulcerative colitis. Inflamm. Bowel Dis. 2011, 17, 680-681. [CrossRef]

9. Le Menn, G.; Neels, J.G. Regulation of Immune Cell Function by PPARs and the Connection with Metabolic and Neurodegenerative Diseases. Int. J. Mol. Sci. 2018, 19, 575. [CrossRef]

10. Dubuquoy, L.; Rousseaux, C.; Thuru, X.; Peyrin-Biroulet, L.; Romano, O.; Chavatte, P.; Chamaillard, M.; Desreumaux, P. PPARgamma as a new therapeutic target in inflammatory bowel diseases. Gut 2006, 55, 1341-1349. [CrossRef] [PubMed]

11. Huang, Q.; Chen, Q. Mediating Roles of PPARs in the Effects of Environmental Chemicals on Sex Steroids. PPAR Res. 2017, 2017. [CrossRef]

12. Wahli, W.; Braissant, O.; Desvergne, B. Peroxisome proliferator activated receptors: Transcriptional regulators of adipogenesis, lipid metabolism and more. Chem. Biol. 1995, 2, 261-266. [CrossRef]

13. Fruchart, J.-C.; Staels, B.; Duriez, P. The role of fibric acids in atherosclerosis. Curr. Atheroscler. Rep. 2001, 3, 83-92. [CrossRef]

14. Ruscica, M.; Baldessin, L.; Boccia, D.; Racagni, G.; Mitro, N. Non-insulin anti-diabetic drugs: An update on pharmacological interactions. Pharmacol. Res. 2017, 115, 14-24. [CrossRef]

15. Berger, J.; Moller, D.E. The Mechanisms of Action of PPARs. Annu. Rev. Med. 2002, 53, 409-435. [CrossRef]

16. Han, L.; Shen, W.-J.; Bittner, S.; Kraemer, F.B.; Azhar, S. PPARs: Regulators of metabolism and as therapeutic targets in cardiovascular disease. Part I: PPAR- $\alpha$. Future Cardiol. 2017, 13, 259-278. [CrossRef]

17. Moreno, S.; Farioli-Vecchioli, S.; Cerù, M.P. Immunolocalization of peroxisome proliferator-activated receptors and retinoid X receptors in the adult rat CNS. Neuroscience 2004, 123, 131-145. [CrossRef]

18. Sertznig, P.; Seifert, M.; Tilgen, W.; Reichrath, J. Present concepts and future outlook: Function of peroxisome proliferator-activated receptors (PPARs) for pathogenesis, progression, and therapy of cancer. J. Cell Physiol. 2007, 212, 1-12. [CrossRef]

19. Magadum, A.; Engel, F. PPAR $\beta$ / ס: Linking Metabolism to Regeneration. IJMS 2018, 19, 2013. [CrossRef]

20. Grygiel-Górniak, B. Peroxisome proliferator-activated receptors and their ligands: Nutritional and clinical implications-A review. Nutr. J. 2014, 13, 17. [CrossRef]

21. Willson, T.M.; Lambert, M.H.; Kliewer, S.A. Peroxisome Proliferator-Activated Receptor $\gamma$ and Metabolic Disease. Annu. Rev. Biochem. 2001, 70, 341-367. [CrossRef] [PubMed] 
22. Delerive, P.; Bosscher, K.D.; Besnard, S.; Berghe, W.V.; Peters, J.M.; Gonzalez, F.J.; Fruchart, J.-C.; Tedgui, A.; Haegeman, G.; Staels, B. Peroxisome Proliferator-activated Receptor $\alpha$ Negatively Regulates the Vascular Inflammatory Gene Response by Negative Cross-talk with Transcription Factors NF-kB and AP-1. J. Biol. Chem. 1999, 274, 32048-32054. [CrossRef] [PubMed]

23. Colville-Nash, P.R.; Qureshi, S.S.; Willis, D.; Willoughby, D.A. Inhibition of inducible nitric oxide synthase by peroxisome proliferator-activated receptor agonists: Correlation with induction of heme oxygenase 1. J. Immunol 1998, 161, 978-984. [PubMed]

24. Chinetti, G.; Fruchart, J.C.; Staels, B. Peroxisome proliferator-activated receptors (PPARs): Nuclear receptors at the crossroads between lipid metabolism and inflammation. Inflamm. Res. 2000, 49, 497-505. [CrossRef] [PubMed]

25. Tan, N.S.; Michalik, L.; Noy, N.; Yasmin, R.; Pacot, C.; Heim, M.; Flühmann, B.; Desvergne, B.; Wahli, W. Critical roles of PPAR $\beta / \delta$ in keratinocyte response to inflammation. Genes Dev. 2001, 15, 3263-3277. [CrossRef] [PubMed]

26. Barish, G.D.; Atkins, A.R.; Downes, M.; Olson, P.; Chong, L.-W.; Nelson, M.; Zou, Y.; Hwang, H.; Kang, H.; Curtiss, L.; et al. PPARס regulates multiple proinflammatory pathways to suppress atherosclerosis. Proc. Natl. Acad. Sci. USA 2008, 105, $4271-4276$. [CrossRef] [PubMed]

27. Ricote, M.; Huang, J.T.; Welch, J.S.; Glass, C.K. The peroxisome proliferator-activated receptor(PPARgamma) as a regulator of monocyte/macrophage function. J. Leukoc. Biol. 1999, 66, 733-739. [CrossRef] [PubMed]

28. Rosenbaum, S.E.; Greenberg, A.S. The Short- and Long-Term Effects of Tumor Necrosis Factor- $\alpha$ and BRL 49653 on Peroxisome Proliferator-Activated Receptor (PPAR) $\gamma 2$ Gene Expression and Other Adipocyte Genes. Mol. Endocrinol. 1998, 12, 1150-1160. [CrossRef]

29. Okuno, A.; Tamemoto, H.; Tobe, K.; Ueki, K.; Mori, Y.; Iwamoto, K.; Umesono, K.; Akanuma, Y.; Fujiwara, T.; Horikoshi, H.; et al. Troglitazone increases the number of small adipocytes without the change of white adipose tissue mass in obese Zucker rats. $J$. Clin. Investig. 1998, 101, 1354-1361. [CrossRef]

30. Hevener, A.L.; Olefsky, J.M.; Reichart, D.; Nguyen, M.T.A.; Bandyopadyhay, G.; Leung, H.-Y.; Watt, M.J.; Benner, C.; Febbraio, M.A.; Nguyen, A.-K.; et al. Macrophage PPAR $\gamma$ is required for normal skeletal muscle and hepatic insulin sensitivity and full antidiabetic effects of thiazolidinediones. J. Clin. Investig. 2007, 117, 1658-1669. [CrossRef]

31. Kostadinova, R.; Wahli, W.; Michalik, L. PPARs in Diseases: Control Mechanisms of Inflammation. CMC 2005, 12, 2995-3009. [CrossRef]

32. Balint, B.; Nagy, L. Selective Modulators of PPAR Activity as New Therapeutic Tools in Metabolic Diseases. EMIDDT 2006, 6, 33-43. [CrossRef]

33. Lefere, S.; Puengel, T.; Hundertmark, J.; Penners, C.; Frank, A.K.; Guillot, A.; de Muynck, K.; Heymann, F.; Adarbes, V.; Defrêne, E.; et al. Differential effects of selective- and pan-PPAR agonists on experimental steatohepatitis and hepatic macrophages $\tau^{2}$. J. Hepatol. 2020, 73, 757-770. [CrossRef]

34. Ullman, T.A.; Itzkowitz, S.H. Intestinal inflammation and cancer. Gastroenterology 2011, 140, 1807-1816. [CrossRef]

35. Lecarpentier, Y.; Claes, V.; Vallée, A.; Hébert, J.-L. Interactions between PPAR Gamma and the Canonical Wnt/Beta-Catenin Pathway in Type 2 Diabetes and Colon Cancer. PPAR Res. 2017, 2017, 5879090. [CrossRef]

36. Mazzei, J.C.; Zhou, H.; Brayfield, B.P.; Hontecillas, R.; Bassaganya-Riera, J.; Schmelz, E.M. Suppression of intestinal inflammation and inflammation-driven colon cancer in mice by dietary sphingomyelin: Importance of peroxisome proliferator-activated receptor $\gamma$ expression. J. Nutr. Biochem. 2011, 22, 1160-1171. [CrossRef]

37. Dou, X.; Xiao, J.; Jin, Z.; Zheng, P. Peroxisome proliferator-activated receptor- $\gamma$ is downregulated in ulcerative colitis and is involved in experimental colitis-associated neoplasia. Oncol. Lett. 2015, 10, 1259-1266. [CrossRef]

38. Gregorio, J.D.; Sferra, R.; Speca, S.; Vetuschi, A.; Dubuquoy, C.; Desreumaux, P.; Pompili, S.; Cristiano, L.; Gaudio, E.; Flati, V.; et al. Role of glycogen synthase kinase- $3 \beta$ and PPAR- $\gamma$ on epithelial-to-mesenchymal transition in DSS-induced colorectal fibrosis. PLoS ONE 2017, 12, e0171093. [CrossRef]

39. McAlpine, C.A.; Barak, Y.; Matise, I.; Cormier, R.T. Intestinal-specific PPAR $\gamma$ deficiency enhances tumorigenesis in ApcMin/+ mice. Int. J. Cancer 2006, 119, 2339-2346. [CrossRef]

40. Stolfi, C.; Pallone, F.; Monteleone, G. Colorectal Cancer Chemoprevention by Mesalazine and Its Derivatives. J. Biomed. Biotechnol. 2012, 2012. [CrossRef]

41. Desreumaux, P.; Ghosh, S. Review article: Mode of action and delivery of 5-aminosalicylic acid-New evidence. Aliment. Pharmacol. Ther. 2006, 24 (Suppl. S1), 2-9. [CrossRef] [PubMed]

42. Schwab, M.; Reynders, V.; Loitsch, S.; Shastri, Y.M.; Steinhilber, D.; Schröder, O.; Stein, J. PPARgamma is involved in mesalazinemediated induction of apoptosis and inhibition of cell growth in colon cancer cells. Carcinogenesis 2008, 29, 1407-1414. [CrossRef] [PubMed]

43. Sugawara, K.; Olson, T.S.; Moskaluk, C.A.; Stevens, B.K.; Hoang, S.; Kozaiwa, K.; Cominelli, F.; Ley, K.F.; McDuffie, M. Linkage to peroxisome proliferator-activated receptor- $\gamma$ in SAMP1/YitFc mice and in human Crohn's disease. Gastroenterology 2005, 128, 351-360. [CrossRef] [PubMed]

44. Puleston, J.; Cooper, M.; Murch, S.; Bid, K.; Makh, S.; Ashwood, P.; Bingham, A.H.; Green, H.; Moss, P.; Dhillon, A.; et al. A distinct subset of chemokines dominates the mucosal chemokine response in inflammatory bowel disease. Aliment. Pharmacol. Ther. 2005, 21, 109-120. [CrossRef] [PubMed]

45. Ricote, M.; Li, A.C.; Willson, T.M.; Kelly, C.J.; Glass, C.K. The peroxisome proliferator-activated receptor-gamma is a negative regulator of macrophage activation. Nature 1998, 391, 79-82. [CrossRef] 
46. Vetuschi, A.; Pompili, S.; Gaudio, E.; Latella, G.; Sferra, R. PPAR- $\gamma$ with its anti-inflammatory and anti-fibrotic action could be an effective therapeutic target in IBD. Eur. Rev. Med. Pharmacol. Sci. 2018, 22, 8839-8848. [CrossRef]

47. Bassaganya-Riera, J.; Reynolds, K.; Martino-Catt, S.; Cui, Y.; Hennighausen, L.; Gonzalez, F.; Rohrer, J.; Benninghoff, A.U.; Hontecillas, R. Activation of PPAR $\gamma$ and $\delta$ by conjugated linoleic acid mediates protection from experimental inflammatory bowel disease. Gastroenterology 2004, 127, 777-791. [CrossRef]

48. Choo, J.; Lee, Y.; Yan, X.; Noh, T.H.; Kim, S.J.; Son, S.; Pothoulakis, C.; Moon, H.R.; Jung, J.H.; Im, E. A Novel Peroxisome Proliferator-activated Receptor (PPAR) $\gamma$ Agonist 2-Hydroxyethyl 5-chloro-4,5-didehydrojasmonate Exerts Anti-Inflammatory Effects in Colitis. J. Biol. Chem. 2015, 290, 25609-25619. [CrossRef]

49. Yang, Y.; Yan, H.; Jing, M.; Zhang, Z.; Zhang, G.; Sun, Y.; Shan, L.; Yu, P.; Wang, Y.; Xu, L. Andrographolide derivative AL-1 ameliorates TNBS-induced colitis in mice: Involvement of NF-кB and PPAR- $\gamma$ signaling pathways. Sci. Rep. 2016, 6. [CrossRef]

50. Dammann, K.; Khare, V.; Lang, M.; Claudel, T.; Harpain, F.; Granofszky, N.; Evstatiev, R.; Williams, J.M.; Pritchard, D.M.; Watson, A.; et al. PAK1 modulates a PPAR $\gamma /$ NF- $\mathrm{kB}$ cascade in intestinal inflammation. Biochim. Biophys. Acta (BBA) Mol. Cell Res. 2015, 1853, 2349-2360. [CrossRef]

51. Wang, D.; Dubois, R.N. The role of COX-2 in intestinal inflammation and colorectal cancer. Oncogene 2010, 29, 781-788. [CrossRef] [PubMed]

52. Shattuck-Brandt, R.L.; Varilek, G.W.; Radhika, A.; Yang, F.; Washington, M.K.; DuBois, R.N. Cyclooxygenase 2 expression is increased in the stroma of colon carcinomas from IL-10(-/-) mice. Gastroenterology 2000, 118, 337-345. [CrossRef]

53. Singer, I.I.; Kawka, D.W.; Schloemann, S.; Tessner, T.; Riehl, T.; Stenson, W.F. Cyclooxygenase 2 is induced in colonic epithelial cells in inflammatory bowel disease. Gastroenterology 1998, 115, 297-306. [CrossRef]

54. Negishi, M.; Katoh, H. Cyclopentenone prostaglandin receptors. Prostaglandins Other Lipid Mediat. 2002, 68-69, 611-617. [CrossRef]

55. Eibl, G. The Role of PPAR- $\gamma$ and Its Interaction with COX-2 in Pancreatic Cancer. PPAR Res. 2008, 2008. [CrossRef]

56. Scher, J.U.; Pillinger, M.H. The anti-inflammatory effects of prostaglandins. J. Investig. Med. 2009, 57, 703-708. [CrossRef]

57. Bento, A.F.; Marcon, R.; Dutra, R.C.; Claudino, R.F.; Cola, M.; Pereira Leite, D.F.; Calixto, J.B. $\beta$-Caryophyllene Inhibits Dextran Sulfate Sodium-Induced Colitis in Mice through CB2 Receptor Activation and PPAR $\gamma$ Pathway. Am. J. Pathol. 2011, 178, 1153-1166. [CrossRef]

58. D'Argenio, G.; Valenti, M.; Scaglione, G.; Cosenza, V.; Sorrentini, I.; Di Marzo, V. Up-regulation of anandamide levels as an endogenous mechanism and a pharmacological strategy to limit colon inflammation. FASEB J. 2006, 20, 568-570. [CrossRef]

59. Liu, J.; Li, H.; Burstein, S.H.; Zurier, R.B.; Chen, J.D. Activation and binding of peroxisome proliferator-activated receptor gamma by synthetic cannabinoid ajulemic acid. Mol. Pharmacol. 2003, 63, 983-992. [CrossRef]

60. Arumugam, M.; Raes, J.; Pelletier, E.; Le Paslier, D.; Yamada, T.; Mende, D.R.; Fernandes, G.R.; Tap, J.; Bruls, T.; Batto, J.-M.; et al. Enterotypes of the human gut microbiome. Nature 2011, 473, 174-180. [CrossRef]

61. Peyrin-Biroulet, L.; Beisner, J.; Wang, G.; Nuding, S.; Oommen, S.T.; Kelly, D.; Parmentier-Decrucq, E.; Dessein, R.; Merour, E.; Chavatte, P.; et al. Peroxisome proliferator-activated receptor gamma activation is required for maintenance of innate antimicrobial immunity in the colon. Proc. Natl. Acad. Sci. USA 2010, 107, 8772-8777. [CrossRef] [PubMed]

62. Byndloss, M.X.; Olsan, E.E.; Rivera-Chávez, F.; Tiffany, C.R.; Cevallos, S.A.; Lokken, K.L.; Torres, T.P.; Byndloss, A.J.; Faber, F.; Gao, Y.; et al. Microbiota-activated PPAR- $\gamma$-signaling inhibits dysbiotic Enterobacteriaceae expansion. Science 2017, 357, 570-575. [CrossRef] [PubMed]

63. Nepelska, M.; de Wouters, T.; Jacouton, E.; Béguet-Crespel, F.; Lapaque, N.; Doré, J.; Arulampalam, V.; Blottière, H.M. Commensal gut bacteria modulate phosphorylation-dependent PPAR $\gamma$ transcriptional activity in human intestinal epithelial cells. Sci. Rep. 2017, 7, 43199. [CrossRef] [PubMed]

64. Zenhom, M.; Hyder, A.; de Vrese, M.; Heller, K.J.; Roeder, T.; Schrezenmeir, J. Prebiotic oligosaccharides reduce proinflammatory cytokines in intestinal Caco-2 cells via activation of PPAR $\gamma$ and peptidoglycan recognition protein 3. J. Nutr. 2011, 141, 971-977. [CrossRef]

65. Damaskos, D.; Kolios, G. Probiotics and prebiotics in inflammatory bowel disease: Microflora 'on the scope'. Br. J. Clin. Pharmacol. 2008, 65, 453-467. [CrossRef]

66. Ley, R.E.; Turnbaugh, P.J.; Klein, S.; Gordon, J.I. Human gut microbes associated with obesity. Nature 2006, $444,1022-1023$. [CrossRef]

67. Claus, S.P.; Guillou, H.; Ellero-Simatos, S. The gut microbiota: A major player in the toxicity of environmental pollutants? NPJ Biofilms Microbiomes 2016, 2, 16003. [CrossRef]

68. Wang, J.; Chen, W.-D.; Wang, Y.-D. The Relationship Between Gut Microbiota and Inflammatory Diseases: The Role of Macrophages. Front. Microbiol. 2020, 11. [CrossRef]

69. Steinbach, E.C.; Plevy, S.E. The role of macrophages and dendritic cells in the initiation of inflammation in IBD. Inflamm. Bowel Dis. 2014, 20, 166-175. [CrossRef]

70. Mosser, D.M.; Edwards, J.P. Exploring the full spectrum of macrophage activation. Nat. Rev. Immunol. 2008, 8, 958-969. [CrossRef]

71. Rugtveit, J.; Nilsen, E.; Bakka, A.; Carlsen, H.; Brandtzaeg, P.; Scott, H. Cytokine profiles differ in newly recruited and resident subsets of mucosal macrophages from inflammatory bowel disease. Gastroenterology 1997, 112, 1493-1505. [CrossRef]

72. Cerovic, V.; Bain, C.C.; Mowat, A.M.; Milling, S.W.F. Intestinal macrophages and dendritic cells: What's the difference? Trends Immunol. 2014, 35, 270-277. [CrossRef] [PubMed] 
73. Smythies, L.E.; Sellers, M.; Clements, R.H.; Mosteller-Barnum, M.; Meng, G.; Benjamin, W.H.; Orenstein, J.M.; Smith, P.D. Human Intestinal Macrophages Display Profound Inflammatory Anergy Despite Avid Phagocytic and Bacteriocidal Activity. Available online: https: / / www.jci.org/articles/view/19229/pdf (accessed on 3 November 2020).

74. Wang, S.; Ye, Q.; Zeng, X.; Qiao, S. Functions of Macrophages in the Maintenance of Intestinal Homeostasis. Available online: https:/ / www.hindawi.com/journals/jir/2019/1512969/ (accessed on 3 November 2020).

75. Arpaia, N.; Rudensky, A.Y. Microbial metabolites control gut inflammatory responses. Proc. Natl. Acad. Sci. USA 2014, 111, 2058-2059. [CrossRef] [PubMed]

76. Smythies, L.E.; Maheshwari, A.; Clements, R.; Eckhoff, D.; Novak, L.; Vu, H.L.; Mosteller-Barnum, L.M.; Sellers, M.; Smith, P.D. Mucosal IL-8 and TGF-beta recruit blood monocytes: Evidence for cross-talk between the lamina propria stroma and myeloid cells. J. Leukoc. Biol. 2006, 80, 492-499. [CrossRef]

77. Smythies, L.E.; Shen, R.; Bimczok, D.; Novak, L.; Clements, R.H.; Eckhoff, D.E.; Bouchard, P.; George, M.D.; Hu, W.K.; Dandekar, S.; et al. Inflammation anergy in human intestinal macrophages is due to Smad-induced IkappaBalpha expression and NF-kappaB inactivation. J. Biol. Chem. 2010, 285, 19593-19604. [CrossRef]

78. Schenk, M.; Bouchon, A.; Seibold, F.; Mueller, C. TREM-1-expressing intestinal macrophages crucially amplify chronic inflammation in experimental colitis and inflammatory bowel diseases. J. Clin. Investig. 2007, 117, 3097-3106. [CrossRef] [PubMed]

79. Szanto, A.; Nagy, L. Retinoids potentiate peroxisome proliferator-activated receptor gamma action in differentiation, gene expression, and lipid metabolic processes in developing myeloid cells. Mol. Pharmacol. 2005, 67, 1935-1943. [CrossRef]

80. Chawla, A.; Barak, Y.; Nagy, L.; Liao, D.; Tontonoz, P.; Evans, R.M. PPAR-gamma dependent and independent effects on macrophage-gene expression in lipid metabolism and inflammation. Nat. Med. 2001, 7, 48-52. [CrossRef]

81. Heming, M.; Gran, S.; Jauch, S.-L.; Fischer-Riepe, L.; Russo, A.; Klotz, L.; Hermann, S.; Schäfers, M.; Roth, J.; BarczykKahlert, K. Peroxisome Proliferator-Activated Receptor- $\gamma$ Modulates the Response of Macrophages to Lipopolysaccharide and Glucocorticoids. Front. Immunol. 2018, 9. [CrossRef]

82. Coelho, M.; Oliveira, T.; Fernandes, R. Biochemistry of adipose tissue: An endocrine organ. Arch. Med. Sci. 2013, 9, 191-200. [CrossRef]

83. Coppack, S.W. Pro-inflammatory cytokines and adipose tissue. Proc. Nutr. Soc. 2001, 60, 349-356. [CrossRef] [PubMed]

84. Spiegelman, B.M.; Flier, J.S. Obesity and the regulation of energy balance. Cell 2001, 104, 531-543. [CrossRef]

85. Cinti, S.; Mitchell, G.; Barbatelli, G.; Murano, I.; Ceresi, E.; Faloia, E.; Wang, S.; Fortier, M.; Greenberg, A.S.; Obin, M.S. Adipocyte death defines macrophage localization and function in adipose tissue of obese mice and humans. J. Lipid Res. 2005, 46, $2347-2355$. [CrossRef] [PubMed]

86. Jernås, M.; Palming, J.; Sjöholm, K.; Jennische, E.; Svensson, P.-A.; Gabrielsson, B.G.; Levin, M.; Sjögren, A.; Rudemo, M.; Lystig, T.C.; et al. Separation of human adipocytes by size: Hypertrophic fat cells display distinct gene expression. FASEB J. 2006, 20, 1540-1542. [CrossRef] [PubMed]

87. Rosen, E.D.; Hsu, C.-H.; Wang, X.; Sakai, S.; Freeman, M.W.; Gonzalez, F.J.; Spiegelman, B.M. C/EBP $\alpha$ induces adipogenesis through PPAR $\gamma$ : A unified pathway. Genes Dev. 2002, 16, 22-26. [CrossRef]

88. Spalding, K.L.; Arner, E.; Westermark, P.O.; Bernard, S.; Buchholz, B.A.; Bergmann, O.; Blomqvist, L.; Hoffstedt, J.; Näslund, E.; Britton, T.; et al. Dynamics of fat cell turnover in humans. Nature 2008, 453, 783-787. [CrossRef]

89. Ponemone, V.; Keshavarzian, A.; Brand, M.I.; Saclarides, T.; Abcarian, H.; Cabay, R.J.; Fletcher, E.; Larsen, B.; Durstine, L.J.; Fantuzzi, G.; et al. Apoptosis and Inflammation: Role of Adipokines in Inflammatory Bowel Disease. Clin. Transl. Gastroenterol. 2010, 1, e1. [CrossRef]

90. Nishihara, T.; Matsuda, M.; Araki, H.; Oshima, K.; Kihara, S.; Funahashi, T.; Shimomura, I. Effect of adiponectin on murine colitis induced by dextran sulfate sodium. Gastroenterology 2006, 131, 853-861. [CrossRef]

91. Shahnazaryan, U.; Wójcik, M.; Bednarczuk, T.; Kuryłowicz, A. Role of Obesogens in the Pathogenesis of Obesity. Medicina (Kaunas) 2019, 55, 515. [CrossRef]

92. Marion-Letellier, R.; Déchelotte, P.; Iacucci, M.; Ghosh, S. Dietary modulation of peroxisome proliferator-activated receptor gamma. Gut 2009, 58, 586-593. [CrossRef]

93. Queiroga, M.R.; Barbieri, R.A.; Ferreira, S.A.; Luchessi, A.D.; Hirata, R.D.C.; Hirata, M.H.; Kokubun, E. Influence of Cardiorespiratory Fitness on PPARG mRNA Expression Using Monozygotic Twin Case Control. J. Diabetes Res. 2015, 2015. [CrossRef] [PubMed]

94. Yang, O.; Kim, H.L.; Weon, J.-I.; Seo, A.Y.R. Endocrine-disrupting Chemicals: Review of Toxicological Mechanisms Using Molecular Pathway Analysis. J. Cancer Prev. 2015, 20, 12-24. [CrossRef] [PubMed]

95. Casals-Casas, C.; Feige, J.N.; Desvergne, B. Interference of pollutants with PPARs: Endocrine disruption meets metabolism. Int. J. Obes. 2008, 32, S53-S61. [CrossRef] [PubMed]

96. Hurst, C.H.; Waxman, D.J. Activation of PPARalpha and PPARgamma by environmental phthalate monoesters. Toxicol. Sci. 2003, 74, 297-308. [CrossRef]

97. Li, L.; Wang, Q.; Zhang, Y.; Niu, Y.; Yao, X.; Liu, H. The Molecular Mechanism of Bisphenol A (BPA) as an Endocrine Disruptor by Interacting with Nuclear Receptors: Insights from Molecular Dynamics (MD) Simulations. PLoS ONE 2015, 10, e0120330. [CrossRef] [PubMed] 
98. Kanayama, T.; Kobayashi, N.; Mamiya, S.; Nakanishi, T.; Nishikawa, J. Organotin compounds promote adipocyte differentiation as agonists of the peroxisome proliferator-activated receptor gamma/retinoid X receptor pathway. Mol. Pharmacol. 2005, 67, 766-774. [CrossRef]

99. Opstelten, J.L.; Beelen, R.M.J.; Leenders, M.; Hoek, G.; Brunekreef, B.; van Schaik, F.D.M.; Siersema, P.D.; Eriksen, K.T.; RaaschouNielsen, O.; Tjønneland, A.; et al. Exposure to Ambient Air Pollution and the Risk of Inflammatory Bowel Disease: A European Nested Case-Control Study. Dig. Dis. Sci. 2016, 61, 2963-2971. [CrossRef]

100. Steenland, K.; Zhao, L.; Winquist, A.; Parks, C. Parks Christine Ulcerative Colitis and Perfluorooctanoic Acid (PFOA) in a Highly Exposed Population of Community Residents and Workers in the Mid-Ohio Valley. Environ. Health Perspect. 2013, 121, 900-905. [CrossRef]

101. Baccarelli, A.; Bollati, V. Epigenetics and environmental chemicals. Curr. Opin. Pediatr. 2009, 21, 243-251. [CrossRef]

102. Dolinoy, D.C.; Huang, D.; Jirtle, R.L. Maternal nutrient supplementation counteracts bisphenol A-induced DNA hypomethylation in early development. Proc. Natl. Acad. Sci. USA 2007, 104, 13056-13061. [CrossRef]

103. Sabatino, L.; Fucci, A.; Pancione, M.; Colantuoni, V. PPARG Epigenetic Deregulation and Its Role in Colorectal Tumorigenesis PPAR Res. 2012, 2012. [CrossRef] [PubMed]

104. Angelis, I.D.; Turco, L. Caco-2 cells as a model for intestinal absorption. Curr. Protoc. Toxicol. 2011, 47. [CrossRef] [PubMed]

105. Martínez-Maqueda, D.; Miralles, B.; Recio, I. HT29 Cell Line. In The Impact of Food Bioactives on Health: In Vitro and Ex Vivo Models; Verhoeckx, K., Cotter, P., López-Expósito, I., Kleiveland, C., Lea, T., Mackie, A., Requena, T., Swiatecka, D., Wichers, H., Eds.; Springer International Publishing: Cham, Switzerland, 2015; pp. 113-124. ISBN 978-3-319-16104-4.

106. Noda, M.; Tatsumi, Y.; Tomizawa, M.; Takama, T.; Mitsufuji, S.; Sugihara, H.; Kashima, K.; Hattori, T. Effects of etodolac, a selective cyclooxygenase-2 inhibitor, on the expression of E-cadherin-catenin complexes in gastrointestinal cell lines. J. Gastroenterol. 2002, 37, 896-904. [CrossRef] [PubMed]

107. Leonard, F.; Collnot, E.-M.; Lehr, C.-M. A Three-Dimensional Coculture of Enterocytes, Monocytes and Dendritic Cells To Model Inflamed Intestinal Mucosa in Vitro. Mol. Pharm. 2010, 7, 2103-2119. [CrossRef] [PubMed]

108. Schwerdtfeger, L.A.; Nealon, N.J.; Ryan, E.P.; Tobet, S.A. Human colon function ex vivo: Dependence on oxygen and sensitivity to antibiotic. PLoS ONE 2019, 14, e0217170. [CrossRef]

109. Benedetti, E.; Viscido, A.; Castelli, V.; Maggiani, C.; d’Angelo, M.; Giacomo, E.D.; Antonosante, A.; Picarelli, A.; Frieri, G. Mesalazine treatment in organotypic culture of celiac patients: Comparative study with gluten free diet. J. Cell. Physiol. 2018, 233, 4383-4390. [CrossRef]

110. Hartman, K.G.; Bortner, J.D.; Falk, G.W.; Yu, J.; Martín, M.G.; Rustgi, A.K.; Lynch, J.P. Modeling inflammation and oxidative stress in gastrointestinal disease development using novel organotypic culture systems. Stem Cell Res. Ther. 2013, 4, S5. [CrossRef]

111. Wirtz, S.; Neurath, M.F. Mouse models of inflammatory bowel disease. Adv. Drug Deliv. Rev. 2007, 59, 1073-1083. [CrossRef]

112. Mizoguchi, A. Animal Models of Inflammatory Bowel Disease. In Progress in Molecular Biology and Translational Science; Elsevier: Amsterdam, The Netherlands, 2012; Volume 105, pp. 263-320. ISBN 978-0-12-394596-9.

113. Rieder, F.; Kessler, S.; Sans, M.; Fiocchi, C. Animal models of intestinal fibrosis: New tools for the understanding of pathogenesis and therapy of human disease. Am. J. Physiol. Gastrointest Liver Physiol. 2012, 303, G786-G801. [CrossRef]

114. Cheesman, S.E.; Guillemin, K. We know you are in there: Conversing with the indigenous gut microbiota. Res. Microbiol. 2007, 158, 2-9. [CrossRef]

115. Yang, Y.; Tomkovich, S.; Jobin, C. Could a Swimming Creature Inform Us on Intestinal Diseases? Lessons from Zebrafish. Inflamm. Bowel Dis. 2014, 20, 956-966. [CrossRef] [PubMed]

116. Wallace, K.N.; Pack, M. Unique and conserved aspects of gut development in zebrafish. Develop. Biol. 2003, 255, 12-29. [CrossRef]

117. Wallace, K.N.; Akhter, S.; Smith, E.M.; Lorent, K.; Pack, M. Intestinal growth and differentiation in zebrafish. Mech. Develop. 2005, 122, 157-173. [CrossRef] [PubMed]

118. Wang, Z.; Du, J.; Lam, S.H.; Mathavan, S.; Matsudaira, P.; Gong, Z. Morphological and molecular evidence for functional organization along the rostrocaudal axis of the adult zebrafish intestine. BMC Genom. 2010, 11, 392. [CrossRef] [PubMed]

119. Danilova, N.; Wilkes, M.; Bibikova, E.; Youn, M.-Y.; Sakamoto, K.M.; Lin, S. Innate immune system activation in zebrafish and cellular models of Diamond Blackfan Anemia. Sci. Rep. 2018, 8, 5165. [CrossRef]

120. Caccia, E.; Agnello, M.; Ceci, M.; Strickler Dinglasan, P.; Vasta, G.R.; Romano, N. Antimicrobial Peptides Are Expressed during Early Development of Zebrafish (Danio rerio) and Are Inducible by Immune Challenge. Fishes 2017, 2, 20. [CrossRef]

121. Zou, J.; Mercier, C.; Koussounadis, A.; Secombes, C. Discovery of multiple beta-defensin like homologues in teleost fish. Mol. Immunol. 2007, 44, 638-647. [CrossRef]

122. He, Q.; Wang, L.; Wang, F.; Wang, C.; Tang, C.; Li, Q.; Li, J.; Zhao, Q. Microbial fingerprinting detects intestinal microbiota dysbiosis in Zebrafish models with chemically-induced enterocolitis. BMC Microbiol. 2013, 13, 289. [CrossRef]

123. Fleming, A.; Jankowski, J.; Goldsmith, P. In vivo analysis of gut function and disease changes in a zebrafish larvae model of inflammatory bowel disease: A feasibility study. Inflamm. Bowel Dis. 2010, 16, 1162-1172. [CrossRef]

124. Brugman, S.; Liu, K.-Y.; Lindenbergh-Kortleve, D.; Samsom, J.N.; Furuta, G.T.; Renshaw, S.A.; Willemsen, R.; Nieuwenhuis, E.E.S. Oxazolone-Induced Enterocolitis in Zebrafish Depends on the Composition of the Intestinal Microbiota. Gastroenterology 2009, 137, 1757-1767.e1. [CrossRef]

125. Renshaw, S.A.; Loynes, C.A.; Trushell, D.M.I.; Elworthy, S.; Ingham, P.W.; Whyte, M.K.B. A transgenic zebrafish model of neutrophilic inflammation. Blood 2006, 108, 3976-3978. [CrossRef] [PubMed] 
126. Camp, J.G.; Jazwa, A.L.; Trent, C.M.; Rawls, J.F. Intronic Cis-Regulatory Modules Mediate Tissue-Specific and Microbial Control of angptl4/fiaf Transcription. PLOS Genet. 2012, 8, e1002585. [CrossRef] [PubMed]

127. Semova, I.; Carten, J.D.; Stombaugh, J.; Mackey, L.C.; Knight, R.; Farber, S.A.; Rawls, J.F. Microbiota regulate intestinal absorption and metabolism of fatty acids in the zebrafish. Cell Host Microbe 2012, 12, 277-288. [CrossRef] [PubMed]

128. Kamada, N.; Seo, S.-U.; Chen, G.Y.; Núñez, G. Role of the gut microbiota in immunity and inflammatory disease. Nat. Rev. Immunol. 2013, 13, 321-335. [CrossRef]

129. He, Q.; Wang, L.; Wang, F.; Li, Q. Role of Gut Microbiota in a Zebrafish Model with Chemically Induced Enterocolitis Involving Toll-Like Receptor Signaling Pathways. Zebrafish 2014, 11, 255-264. [CrossRef] [PubMed]

130. Broeder, M.J.D.; Kopylova, V.A.; Kamminga, L.M.; Legler, J. Zebrafish as a Model to Study the Role of Peroxisome ProliferatingActivated Receptors in Adipogenesis and Obesity. PPAR Res. 2015, 2015, 358029. [CrossRef]

131. Oka, T.; Nishimura, Y.; Zang, L.; Hirano, M.; Shimada, Y.; Wang, Z.; Umemoto, N.; Kuroyanagi, J.; Nishimura, N.; Tanaka, T. Diet-induced obesity in zebrafish shares common pathophysiological pathways with mammalian obesity. BMC Physiol. 2010, 10, 21. [CrossRef]

132. Hu, P.; Chen, X.; Whitener, R.J.; Boder, E.T.; Jones, J.O.; Porollo, A.; Chen, J.; Zhao, L. Effects of Parabens on Adipocyte Differentiation. Toxicol. Sci. 2013, 131, 56-70. [CrossRef]

133. Perugini, M.; Merola, C.; Amorena, M.; D’Angelo, M.; Cimini, A.; Benedetti, E. Sublethal exposure to propylparaben leads to lipid metabolism impairment in zebrafish early-life stages. J. Appl. Toxicol. 2020, 40, 493-503. [CrossRef]

134. Tse, W.K.F.; Yeung, B.H.Y.; Wan, H.T.; Wong, C.K.C. Early embryogenesis in zebrafish is affected by bisphenol A exposure. Biol. Open 2013, 2, 466-471. [CrossRef]

135. Ortiz-Villanueva, E.; Jaumot, J.; Martínez, R.; Navarro-Martín, L.; Piña, B.; Tauler, R. Assessment of endocrine disruptors effects on zebrafish (Danio rerio) embryos by untargeted LC-HRMS metabolomic analysis. Sci. Total Environ. 2018, 635, 156-166. [CrossRef] [PubMed] 